\title{
The Influence of Organizational Climate, Coordination and Organizational Commitment to Collective Leadership in Collegial Community Consultants of the People of the Republic of Indonesia
}

\author{
Jazilul Fawaid*, \\ Institut Pemerintahan Dalam Negeri Jakarta \\ E-mail: jazzilfawaid@gmail.com \\ Bahrullah Akbar, \\ Institut Pemerintahan Dalam Negeri Jakarta \\ Khasan Effendy, \\ Institut Pemerintahan Dalam Negeri Jakarta \\ Sampara Lukman \\ Institut Pemerintahan Dalam Negeri Jakarta
}

Received: Jul. 9, 2020 Accepted: Sept. 14, 2020 Online published: Sept. 26, 2020

doi:10.5296/jpag.v10i3.17337ＵRL: https://doi.org/10.5296/jpag.v10i3.17337

\begin{abstract}
This research uses a quantitative research approach. The research sample of 176 respondents from a population of 313 people. Secondary data collection using library research; Primary data collection using questionnaire and interview techniques. Data processing uses SEM analysis and descriptive analysis developed with observer triangulation analysis. The results of the research analysis are The magnitude of the influence of Organizational Climate on Collective Leadership in the People's Consultative Assembly reached 0.67. The magnitude of the influence of the Coordination on the Collective Leadership Collegial in the People's Consultative Assembly reached 0.62. The magnitude of the influence of Organizational
\end{abstract}


Commitment on Collective Leadership in the People's Consultative Assembly reached 0.56. Development of Concept I obtained the Organizational Support Strategy for the Collective Leadership in the Indonesian People's Consultative Assembly. Development of Concept II obtained is Optimizing the integration of roles. Development of Concept III obtained is collegial at the People's Consultative Assembly of the Republic of Indonesia, namely Actualization of continuation commitments.

Keywords: organizational climate, coordination, organizational commitment and collective leadership

\section{Introduction}

The complexity that occurs in the People's Consultative Assembly Republic of Indonesia (MPR RI) container consisting of various political party factions as well as from a variety of social, cultural and educational backgrounds makes it a challenge for the Chair of the MPR $\mathrm{RI}$ in synergizing in order to achieve the realization of one of the strategic objectives of the MPR RI namely realizing the implementation of authority and the constitutional duties of the People's Consultative Assembly in accordance with the provisions of the 1945 Constitution of the Republic of Indonesia and the laws and regulations based on the principles of legality, the principle of kinship, deliberation, and mutual cooperation (MPR Strategic Plan 2014-2019).

The role of achieving strategic goals carried by the leadership composition under the "captain" Dr. (H.C.) Zulkifli Hasan, S.E., M.M. as Chair of the Republic of Indonesia Republic of Indonesia Period 2014-2019 and assisted by his representatives consisting of E. E. Mangindaan, S.IP .; H. Mahyudin, S.T., M.M .; Dr. (H.C.) Oesman Sapta Odang; Dr. H.M. Hidayat Nur Wahid, M.A has completed his task of socializing the 4 National Pillars. In one period of leadership Zulkifli Hasan (2014-2019) more applied the leadership pattern of communication "political lobbying" as he conveyed to Tempo online media (17 Sept 2019) where "Chairman of the People's Consultative Assembly (MPR), Zulkifli Hasan said the political lobby was MPR has succeeded in presenting a political tradition that is worth guarding for the life of democracy in Indonesia. "

The role of political lobbying by Zulkifli Hasan in maintaining the balance and conditions of Indonesia's political temperature needs to be appreciated, because since the preparation, implementation and after the Presidential Election for the 2014-2019 period won by the pair Ir. Joko Widodo and Jusuf Kalla voters in Indonesia were split into two and always gave rise to "hot" political temperatures. The steps of the political lobby of the Chair of the People's Consultative Assembly to change this tradition need to be considered well for the nation's progress in addressing these different political views.

The first step that seized the public's attention Zulkifli Hasan was by successfully lobbying the Gerindra Party Chairperson, Prabowo Subianto (Vice President) during the inauguration of the President and Vice President-elect Jokowi and JK. The results of this political lobbying are inseparable from the movement of all elements of the leadership and deputy leadership of the People's Consultative Assembly in maintaining political stability. "Based on that, we actually lobbied with Oesman Sapta, so Pak Prabowo was willing to attend that day 
(Tempo.co.id, 2019)

The second lobby, namely the efforts made by the MPR in the socialization of the four pillars of nationalism to all Indonesian people, was also carried out by the Government. These efforts made the Government form a special body called the Pancasila Ideology Development Board (BPIP), encouraging the government to include Bhinneka Tunggal Ika into all educational curricula starting from kindergarten. Zulkifli said, the MPR also gave recommendations to reform the national development planning system with the State Guidelines Outline model as a direction for the administration of the state and was followed up by the government.

Through public hearings, various studies by the MPR Review Board, supported by the MPR Assessment Institute, Zulkifli felt it was necessary to provide recommendations so that the results of the aspirations and studies obtained could be made material for the next Term of Assembly MPR. The main points of aspirations and studies that are recommended are among others the State Policy Principles. MPR Term of Office 2019-2024 needs to deepen the results of the 2014-2019 Term Period MPR study regarding the substance and legal form.

One of the challenges faced by the leaders of the MPR RI is to synchronize members who come from different backgrounds, because in principle, the leadership that takes place in the MPR RI is collegially collective. If you examine further on the State Administration System in Indonesia after the amendment of the 1945 Constitution has undergone many changes. In addition to what is evident in the system of administering a democratic government transition through elections, many changes have also taken place with the face of the MPR. The practices and patterns of constitutional relations in Indonesia have also changed. If you look at the most recent portrait of the MPR, the 2004-2009 period is the smallest in history. Where the number of leadership personnel, only four people (1 chairman and 3 deputy chairs).

The high expectations of the public for the role of the Indonesian People's Consultative Assembly today is certainly a challenge for the leadership of the Indonesian People's Consultative Assembly, because people still expect and need leaders. They only want leaders who hold a service ethic and truly appreciate their intelligence and contribution of thought. In addition, the people give great hope to leaders who prioritize the principles before politics and others before their own interests. On this basis every leader must have a way to gain the trust and confidence of their followers (credibility).

The magnitude of the role of the MPR RI in providing life in the nation and state certainly cannot be separated from the role of the leadership of the organization which has been given the mandate by the constitution in the next 5 years (2019-2024). The leadership of the MPR RI as an institutional activator is demanded to be able to synchronize the community in the assembly, so that the presence of the leader of the MPR RI has always been a unique thing to study, this is because the tasks and functions of the MPR leadership are not just leading but also can maintain connectivity and collegially collegially in order to move the pace of the community at the place of the assembly (Dhofier, 1994).

The existence of a leader plays an important role in an organization. The role of a leader is as 
a direction and direction in the future (direct setter), change agent (change agent), negotiator (spokesperson), and as a coach (coach). The study of leadership is carried out in various ways, depending on the methodology chosen by the researcher and the definition of leadership. Most of the leadership research includes the traits approach of leaders (traits approach), leader behavior (behavior approach), influences (power-influence approach) and situational approach (situational approach). (McClelland, 1985; Compball, \& Grant, 1974 in Chen, 2002). Most recent theories of leadership have been greatly influenced by James McGregor Burns (1978).

One of the characteristics of leadership that deserves to be examined is leadership that is collective in nature where collective leadership is not new in the realm of archipelago leadership. And the collective leadership lately began to be as unpopular as it had been since it was uniformed during the new order through Law No. 5 of 1974 and Law No. 5 of 1979 concerning Village Government. Although this system is not widely used by the community. Among villages in Lombok and Bali up to now hold this system firmly, as well as in certain circles such as among the pesantren education world it is also not uncommon to use this system.

Collegial collective leadership can be interpreted as a collaborative leadership process that is mutually beneficial and allows all elements to contribute to building an agreement that is ultimately for a common goal (Winda, 2016). This opinion is in line with the culture formed in the MPR RI, where every decision taken by the leadership of the MPR RI allows getting input from its members so that decisions taken collectively show a collaboration between individuals or groups or groups.

The phenomenon of collegial collective leadership certainly does not stand alone, meaning that many factors influence the thinking of the collegial collective leadership. The author identified that there are several factors that might influence the collegial collective leadership, including the organizational climate, coordination and organizational commitment.

Organizational climate influences HR policy practices that are accepted by members of the organization. Human resources (HR) is one of the main factors in competition in the global era, so we must think about how to create quality human resources and have high competitiveness and skills in competition.

The coordination meant is integration to arrange and unite members in various units or work units by making effective the achievement of vertical information systems, lateral relations, liaison roles, committee members and task forces, integrating roles, role liaison managerial and matrix organization (Sabardi , 2001: 204).

Meanwhile, the organizational commitment that emanated from a joint commitment to the organization with a measure of the willingness of the members of the People's Consultative Assembly of the Republic of Indonesia (2014-2019 Period) to be able to survive with an organization in the future by paying attention to affective commitment, continuance commitment, and normative commitment (Kaswan, 2012: 293)

With such a description of the tasks and authority of the Indonesian MPR, collegial collective 
leadership does not appear to stand on its own meaning in other assumptions that the success of the leadership of the MPR RI in leading this large institution cannot possibly be maximized in carrying it out without the existence of overall collectivity among members of the assembly (collegial). This phenomenon can be seen from every decision that must be agreed by all members of the assembly, so that the existence of a collegial collective leader really needs to be prioritized. But collegial collective leadership does not stand alone, there are many factors that influence it, including what should be suspected and needs to be done further research is the organizational climate which according to the author every change of leadership changes, the organizational climate will change because of the different composition and character of the members, as well as the coordination established from each member of the Indonesian People's Consultative Assembly needs to be accommodated and bridged by the leaders of the Indonesian People's Consultative Assembly so that the assembly can run well, as well as a commitment factor to the organization of each member that puts forward the common interests rather than the personal interests of the group or group.

For this premise, the author can take the reasons for the selection of the title, namely: The Effect of Organizational Climate, Organizational Coordination and Commitment on Collective Leadership in the People's Consultative Assembly of the Republic of Indonesia (2014-2019 Period).

Research Objectives: By identifying problems, limiting problems and asking research questions, the research objectives are set as follows:

1. Analyzing the influence of the Organizational Climate on the Collective Leadership of the Colegial in the People's Consultative Assembly of the Republic of Indonesia;

2. Analyzing the effect of Coordination on the Collective Leadership of the Colegial in the People's Consultative Assembly of the Republic of Indonesia;

3. Analyzing the effect of Organizational Commitment to the Collective Leadership in the People's Consultative Assembly of the Republic of Indonesia;

4. Obtaining the development of concepts from the analysis of the influence of the Organizational Climate on the Collective Leadership in the Indonesian People's Consultative Assembly;

5. Obtaining the development of what concepts from the analysis of the influence of Coordination on the Collective Leadership of the Colegial in the People's Consultative Assembly of the Republic of Indonesia;

6. Obtaining the development of concepts from the analysis of the influence of Organizational Commitment to the Collective Leadership in the People's Consultative Assembly of the Republic of Indonesia.

\section{Literature Study}

Organizational Climate: Organizational climate objectively exists, occurs in every organization, and influences the behavior of members of the organization, but can only be measured indirectly through the perception of members of the organization. This means that researchers who want information about the climate of an organization need to capture it 
using questionnaires, interviews and observations from members of the organization. Dimensions and indicators of the organization's climate must be developed to measure the organization's climate.

Dimensions of organizational climate are elements, factors, characteristics or characteristics of organizational climate variables. The climate dimensions of an organization consist of various types and differ in each organization. Altman (2000) suggests that studies conducted by organizational climate experts show at least 460 types of work environments with their own organizational climate.

Stringer (2002) suggests that the characteristics or dimensions of organizational climate affect the motivation of organizational members to behave in certain ways. Therefore, the organizational climate can be described and measured in terms of six benchmarks namely structure, standards, responsibilities, rewards, support and commitment. From the definition of Stringer (2002), the conceptual definition is drawn up that the organizational climate in the Indonesian People's Consultative Assembly is an organizational characteristic that can influence the motivation of members of the organization to behave in certain ways that can be measured through structure, standards, responsibility, respect and support.

Coordination: Mooney in Sutarto (1998: 141) argues that the notion of coordination is "The orderly arrangement of group effort, to provide unity of action in the pursuit of common purpose." Thus Mooney considers that coordination is a business arrangement of a group of people on a regular basis to create a unity of action in working towards the achievement of a goal. Organizational arrangements for groups or organizations are indeed necessary, bearing in mind that the organization consists of a number of work units that have different functions but are bound by a single unified objective.

According to Agus Sabardi (2001: 205), there are three techniques for improving effective coordination through this basic management, namely:

1. Managerial hierarchy. The chain of command in the topmost organization starting from the top of the organization down to the lowest level can connect between the members of the organization and the units in the organization. The chain of command is a channel of information flow and cooperation between these units.

2. Rules and procedures. An organization uses rules and procedures to expedite routine events and activities in the organization. The subordinates by following the rules and procedures that apply, can carry out activities quickly and independently so that managers have enough time to handle new things or special events.

3. Plans and objectives. Effective coordination can be achieved through plans and objectives ensuring that all units can direct their efforts towards the same targets.

According to Agus Sabardi (2001: 205), effective coordination can be achieved by:

1. Vertical information system. This system can facilitate the flow of data both from the top level of the organization down and from the bottom up. Communication can occur through the chain of command or outside the chain of command in the organization. 


\section{Ml Macrothink}

Journal of Public Administration and Governance

2. Lateral relations. The simplest form of lateral relations is direct contact between individuals who must relate in the same situation or problem.

3. The role of the connector also facilitates lateral relations. If contact between departments increases significantly, it is necessary to create a liaison role and appoint unit members for the task. Here, the liaison has the task of accelerating and facilitating the flow of information and communication between departments.

4. Committee and task force. The committee is usually formally organized by holding meetings that are scheduled regularly. Generally a fixed parts of the structure of an organization, the committee deals with problem solving and decisions. Task forces are formed when needed for special problems.

5. Integration of roles. It is created when a product, service or project that involves several departments requires continuous coordination and attention from just one person. "Integrators" act like diplomats, speaking the language of a group or departmental attitude (for example computer programmers and line supervision).

6. The role of managerial liaison. This role is needed if the integration position described above does not coordinate a particular task effectively. A liaison manager has formal unit authority involved in a project. This authority to control the budgets of all units ensures that they work together to achieve the overall goals of the organization.

7. Matrix organization. With matrix organizations, project managers and functional managers can direct a group of employees who are accountable to both of them.

Organizational Commitment: Porter, Mowday and Steers (1982) define organizational commitment as the relative strength of the individual in identifying his or her involvement in the organization. This can be characterized by three things, namely:

1. Acceptance of organizational values and goals.

2. Readiness and willingness to strive earnestly on behalf of the organization.

3. Desire to maintain membership in the organization (become part of the organization).

Organizational commitment above can be concluded that organizational commitment is an attitude shown by individuals with the identification, involvement and loyalty to the organization. Also, there is a desire to remain in the organization and not be willing to leave the organization for any reason. Kaswan (2012: 293) explains that organizational commitment is a measure of the willingness of employees to stay with a company in the future by paying attention to affective commitment, continuance commitment, and normative commitment. Based on Kaswan's theory (2012: 293) organizational commitment is a measure of the willingness of the members of the People's Consultative Assembly of the Republic of Indonesia (2014-2019 period) to be able to survive with an organization in the future by paying attention to affective commitment, continuance commitment, and normative commitment 


\section{Methods}

Research using quantitative research methods. 71 manifest variables developed from driven theory were made into 65 research questionnaire items. The research questionnaire was prepared using a Likert scale. The research sample of 176 respondents was taken from 313 populations using the Slovin formula and distributed with the stratified random sampling technique. Secondary data collection from various books and documents using the Study of Literature, the collection of quantitative primary data from research samples using Questionnaire and Observation Techniques. Data analysis using Structural Equation Models Analysis.

\section{Results and Discussion}

First Hypothesis Test Results: The test results show that the t-count (12.03) is greater than the critical significance value (1.96), then $\mathrm{H} 0$ is rejected and $\mathrm{H} 1$ is accepted. This means: there is a significant influence of exogenous latent variables Organizational Climate on endogenous latent variables Collegial Collective Leadership in the MPR RI and significant among the Organizational Climate exogenous latent variables to the endogenous latent variables Colegial Collective Leadership in the MPR RI intertwines causal relationships. The amount of influence is determined by the organizational structure, organizational standards, responsibilities, rewards, organizational support.

The magnitude of the path coefficient value of the exogenous latent variables of the Organizational Climate to the endogenous latent variables of the Collegial Collective Leadership in the MPR RI is 0.88. The magnitude of the influence of exogenous latent variables Organizational Climate on endogenous latent variables Collective Leadership Colegial is determined by the organizational structure, organizational standards, responsibilities, rewards, organizational support.

Second hypothesis test results: The test results show that the t-count (11.45) is greater than the critical significance value (1.96), then $\mathrm{H} 0$ is rejected and $\mathrm{H} 1$ is accepted. This means: there is a significant influence of exogenous latent variables Coordination on endogenous latent variables Collegial Leadership in the MPR RI and meaningful among the exogenous latent variables the amount of influence is determined by the vertical information system, literal relations, the role of the liaison, the committee and task force, the integration of roles, the role of liaison managerial and organizational matrix.

Third hypothesis test results: The test results show that the t-count value (10.59) is greater than the critical significance value (1.96), then $\mathrm{H} 0$ is rejected and $\mathrm{H} 1$ is accepted. This means: there is a significant influence of exogenous latent variables Organizational Commitment to endogenous latent variables Collective Leadership in the MPR RI and meaningful among the exogenous latent variables Organizational Commitment to the endogenous latent variables Collective Leadership in the MPR RI is interwoven causal relationships. The amount of influence is determined by affective commitment, continuance commitment and normative commitment. The magnitude of the path coefficient value of the exogenous latent variable Organizational Commitment to the endogenous latent variable The collegial collegial leadership in the MPR RI is 0.75. The magnitude of the influence of exogenous latent 
variables Organizational Commitment to endogenous latent variables Collective Leadership Colegial is determined by affective commitment, continuance commitment and normative commitment.

Development of the first concept: Confirmatory Factor Analysis (CFA) results show that the Dimensions of Organizational Support are the most dominant factors in the process of establishing the magnitude of the influence of exogenous latent variables Organizational Climate on endogenous latent variables Collective Leadership in the MPR RI. In quantitative research that uses SEM analysis, the results of this CFA are seen as a research finding. Furthermore, the results of this CFA are used as the basis for Concept Development and as a basis for forming interview guidelines to sharpen the development of concepts.

Development of the second concept: The results of the Confirmatory Factor Analysis (CFA) show that the Dimension of the Integration of the Role is the most dominant factor in the process of establishing the magnitude of the influence of exogenous latent variables. Coordination of endogenous latent variables. In quantitative research that uses SEM analysis, the results of this CFA are seen as a research finding.

Development of the third concept: Confirmatory Factor Analysis (CFA) results show that the Continuation Commitment Dimension is the most dominant factor in the process of establishing the magnitude of the influence of exogenous latent variables Organizational Commitment on endogenous latent variables Collective Leadership in the MPR RI. In quantitative research that uses SEM analysis, the results of this CFA are seen as a research finding.

\section{Closing}

The conclusions obtained from the discussion of results using statistical analysis and descriptive analysis are as follows 1) The magnitude of the influence of Organizational Climate on Collective Leadership in the People's Consultative Assembly reached 0.67, somewhat strong and significant, because tvalue> ttable (12.03> 1.96), theoretical Hypothesis was accepted. The amount of influence is determined by the dimensions of organizational structure, organizational standards, responsibilities, rewards, organizational support; 2) The magnitude of the influence of Coordination on Collective Leadership in the People's Consultative Assembly reached 0.62, somewhat strong and significant, because tvalue> ttable (11.45> 1.96), theoretical Hypothesis was accepted. The magnitude of the influence is determined by the dimensions of the vertical information system, literal relations, the role of the liaison, the committee and task force, the integration of roles, the role of the liaison managerial and organizational matrix.

The magnitude of the influence of Organizational Commitment on Collective Leadership in the People's Consultative Assembly reached 0.56, quite strong and significant, because tvalue> ttable (10.59> 1.96), then Theoretical Hypothesis was accepted. The amount of influence is determined by the dimensions of affective commitment, continuance commitment and normative commitment. Development of Concept I obtained from the discussion of the influence of Organizational Climate on Collective Leadership in the 
People's Consultative Assembly of the Republic of Indonesia, namely the Organizational Support Strategy for the Collective Leadership in the Indonesian People's Consultative Assembly is tactics, tips, procedures and approaches to achieve goals and objectives certain through the implementation of programs and activities to increase all resources which includes optimizing the formulation of trust, openness and working groups in each line of the organization. Development of Concept II obtained from the discussion of the Coordination of Collective Leadership in the People's Consultative Assembly of the Republic of Indonesia, namely the optimization of the integration of the roles of the Collective Collective Leadership in the Indonesian People's Consultative Assembly is a technical unification of all forms of interests adopted by members by prioritizing the interests of the Nation of the Nation namely by paying attention to the availability of time periods, group attitudes, and group control. Development of Concept III obtained from the discussion of Organizational Commitment to the Collective Leadership in the Indonesian People's Consultative Assembly, namely the Actualization of Continuing Commitment to the Collective Leadership in the Indonesian People's Consultative Assembly is a periodic organizational managerial model specifically designed to achieve specific goals and objectives through the implementation of programs and organizational management activities.

\section{Reference}

Agus, S. (2001). Pengantar Manajemen, Yogyakarta: Unit Penerbit Dan Percetakan Akademi Manajemen Perusahaan YKPN.

Altman, E. I. (2013). Predicting financial distress of companies: revisiting the Z-score and ZETA® models. In Handbook of research methods and applications in empirical finance. Edward Elgar Publishing. https://doi.org/10.4337/9780857936097.00027

Arikunto, S. (1998). Prosedur Penelitian: Suatu Pendekatan Praktek Dan. Edisi revisi IV. Jakarta: Rineka Cipta.

Burns, J. M. (1978). Leadership. Michigan: Harper \& Row.

Strong, C. F. (1996). Modern Political Constitusions: an Introductions to the Comparative Study of Their History and Existing, The English Book Society and Sidgwick \& Jackson Limited, London.

Dhofier, Z. (1994). Tradisi Pesantren. Jakarta: LP3ES.

Poelje, V. G. (1953). Algemene Inleiding tot de Bestuurskunde, Alpen aan den Rijn, N. Samson NV.

Kaswan, M. M. (2012). Manajemen sumber daya manusia untuk keunggulan bersaing organisasi. Edisi Pertama. Cetakan Pertama. Penerbit Graha Ilmu. Yogyakarta.

Mowday, R. T., Porter, L. W., \& Steers, R. M. (2013). Employee-organization linkages: The psychology of commitment, absenteeism, and turnover. Academic press.

Sabardi, A. (2001). Manajemen Pengantar.

Steers, R. M. (1988). Terj: Magdalena Jamin, Efektivitas Organisasi, Jakarta: Erlangga. 


\section{Macrothink}

Journal of Public Administration and Governance ISSN 2161-7104 2020, Vol. 10, No. 3

Stringer, R. (2002). Leadership and organizational climate. Upper Saddle River, NJ: Prentice-Hall.

Sutarto. (1998). Dasar-Dasar Kepemimpinan Administrasi, Yogyakarta: Gajah Mada University Press

Nuridin, S. E., Nuridin, M. M., \& Septiani, W. L. (2016). PENGARUH KEPEMIMPINAN DAN MOTIVASI TERHADAP KINERJA KARYAWAN PT. ASTRA HONDA MOTOR DI CIKAMPEK. Jurnal Manajemen Bisnis Krisnadwipayana, 4(3). https://doi.org/10.35137/jmbk.v4i3.62

\section{Copyright Disclaimer}

Copyright for this article is retained by the author(s), with first publication rights granted to the journal.

This is an open-access article distributed under the terms and conditions of the Creative Commons Attribution license (http://creativecommons.org/licenses/by/4.0/). 